\title{
PENGARUH LINGKUNGAN KERJA DAN MOTIVASI TERHADAP KINERJA KARYAWAN PADA CYCLO COFFEE \& APPAREL JAKARTA SELATAN
}

\author{
1Rizki Triharyanto, ${ }^{2 *}$ Derizka Inva Jaswita \\ Universitas Pamulang, Tangerang, Banten, Indonesia \\ *dosen02041@unpam.ac.id
}

\begin{abstract}
Abstrak
Penelitian ini bertujuan untuk mengetahui pengaruh Lingkungan Kerja dan Morivasi terhadap Kinerja Karyawan pada Cyclo Coffee \& Apparel Jakarta Selatan, untuk mengetahui bagaimana pengaruh Lingkungan Kerja terhadap Kinerja Karyawan pada Cyclo Coffee \& Apparel Jakarta Selatan, untuk mengetahui bagaimana pengaruh Motivasi terhadap Kinerja Karyawan pada Cyclo Coffee \& ApparelJakarta Selatan. Metode yang digunakan pada penelitian ini yaitu metode kuantitatif, yaitu melalui pendekatan, pengumpulan data dan analisa menggunakan statistik. Diketahui nilai signifikan untuk pengaruh X2 (motivasi) terhadap Y (kinerja karyawan) adalah sebesar $0.000<0.05$ dan nilai thitung > ttabel $(1.680>1.676)$ sehingga dapat disimpulkan bahwa terdapat pengaruh X1 dan X2 terhadap Y secara bersama. Hal ini berarti Lingkungan Kerja dan Motivasi cukup memiliki peranan dalam meningkatkan Kinerja Karyawan pada Cyclo Coffee \& Apparel Jakarta Selatan.
\end{abstract}

Kara Kunci: Lingkungan Kerja, Motivasi, Kinerja Karyawan

\section{Abstract}

This study aims to determine the effect of the work environment and motivation on employee performance at Cyclo Coffee $\mathcal{E}$ ApparelSouth Jakarta, to find out how the influence of the work environment on employee performance at Cyclo Coffee \& ApparelSouth Jakarta, to find out how motivation affects employee performance at Cyclo Coffee \& Apparel South Jakarta The method used in this research is quantitative method, namely through the approach, data collection and analysis using statistics is known that the significant value for the influence of $X 2$ (motivation) on $Y$ (employee performance) is $0.000<0.05$ and the value of tcount $>$ ttable $(6.984>1.676)$ so it can be concluded that there is an influence X1 and X2 against $Y$ together. This means that the Work Environment and Motivation have a sufficient role in improving Employee Performance at Cyclo Coffee $\mathcal{E}$ Apparel, South Jakarta.

Keywords: Work Environment, Motivation, Employee Performance

\section{PENDAHULUAN}

Untuk menciptakan kinerja karyawan yang tinggi, dibutuhkan adanya peningkatan kerja yang optimal dan mampu mendayagunakan potensi Sumber Daya Manusia yang dimiliki oleh karyawan guna menciptakan tujuan perusahaan, sehingga akan memberikan kontribusi positif bagi perkembangan perusahaan. Memotivasi karyawan juga tidak kalah penting untuk meningkatkan kinerja mereka. Motivasi adalah adalah suatu kondisi atau keadaan yang dapat mendorong seseorang dengan suatu cara agar dapat bersedia secara ikhlas tanpa paksaan untuk peningkatan kinerja dalam pencapaian tujuan-tujuan perusahaan bahwa pemberian motivasi pada karyawan di dalam perusahaan yang sangatlah penting.

Cyclo Coffee \& Apparel Jakarta Selatan adalah kedai kopi modern yang dirancang khusus untuk melayani dan memberikan cita rasa kopi yang otentik untuk klub-klub sepeda maupun masyarakat umum. Cyclo Coffee \& ApparelJakarta Selatan berletak di Gedung Crumble Crew, jl. Tulodong Bawah No. 1 A, RT. 008/RW. 004, Kebayoran Baru, Jakarta Selatan 12190. Cyclo Coffee \& ApparelJakarta Selatan meiliki 52 orang karyawan. Dalam hal ini Cyclo coffee \& ApparelJakarta Selatan berorientasi bagaimana lingkungan kerja 
mempengaruhi kinerja karyawan sehingga mendapatkan hasil yang sesuai. Berdasarkan hasil pengamatan dan observasi penulis, kinerja karyawan Cyclo Coffee \& Apparel Jakarta Selatan belum optimal. Lingkungan kerja pada Cyclo Coffee \& Apparel Jakarta Selatan terbilang masih belum cukup untuk dikatakan lingkungan kerja ideal bagi para karyawan seperti penerangan yang kurang terang dan desain bar yang membuat efisiensi kerja karyawan berkurang. Permasalahan yang ada pada Cyclo Coffee \& Apparel Jakarta Selatan adalah kurangnya motivasi yang diberikan pimpinan baik berupa material maupun nonmaterial. Diantaranya kurang kepuasan karyawan dalam pemberian penghargaan baik fisik maupun non fisik terhadap prestasi yang didapat seperti tidak adanya program karyawan terbaik setiap bulannya dan interaksi terbatas antara pimpinan dengan karyawan yang kadang membuat karyawan merasa pendapatnya tidak diperlukan untuk mencapai tujuan perusahaan serta kurangnya kesiapan manajemen Cyclo Coffee \& Apparel Jakarta Selatan untuk mengatur jalannya operasional dan kesejahteraan karyawan.

Kinerja karyawan yang optimal sangat penting bagi karyawan Cyclo Coffee \& Apparel Jakarta Selatan, yang mengharuskan karyawannya memiliki kinerja yang optimal dan sanggup untuk bekerja dengan loyalitas. Setiap perusahaan jasa makanan dan minuman selalu memberikan pelayanan terbaik untuk para pelanggan, agar para pelanggan tidak kecewa dan selalu datang kembali untuk membeli makanan dan minuman perusahaan jasa makanan dan minuman tersebut. Tanpa adanya kinerja karyawan yang baik di perusahaan ini, perusahaan tidak akan memiliki pelanggan yang banyak dan tidak akan bisa survive hingga bertahan lama. Karyawan dalam melakukan suatu pekerjaan hendaknya memiliki kinerja yang tinggi.

rekapitulasi absen karyawan Cyclo Coffee \& Apparel Jakarta Selatan pada dua tahun terakhir, yaitu tahun 2018 dan 2019. Banyaknya karyawan yang tidak hadir ke tempat kerja. Seperti pada tahun 2018, dengan jumlah 52 orang karyawan dengan 300 hari kerja terdapat karyawan yang tidak hadir tanpa keterangan (alfa) sebanyak 6 orang, karyawan yang tidak hadir kerja dengan keterangan sakit sebanyak 16 orang, karyawan yang tidak hadir kerja dengan keterangan izin sebanyak 3 orang. Total karyawan yang tidak hadir kerja pada tahun 2018 sebanyak 25 orang. Di tahun selanjutnya, yaitu 2019, terjadi peningkatan ketidakhadiran kerja pada karyawan dengan total 36 orang, yang dimana dengan jumlah hari kerja dan jumlah karyawan yang sama terdapat 9 orang yang tidak hadir kerja tanpa keterangan (alfa), 14 orang yang tidak hadir kerja dengan keterangan sakit, serta 13 orang yang tidak hadir kerja dengan keterangan izin. Dari tabel tersebut dapat disimpulkan bahwa masih kurang sadarnya para karyawan akan hari kerja dan produktifitas Cyclo Coffee \& Apparel Jakarta Selatan berbanding lurus dengan kuantitas produk yang dihasilkan. Masih terdapat juga karyawan yang terlambat datang ke tempat kerja. Banyak karyawan yang tidak peduli terhadap peraturan perusahaan mengakibatkan gangguan pada produktivitas kerja. Walaupun sudah terdapat aturan bahwa setiap karyawan yang terlambat akan menerima pemotongan uang service tidak perduli durasi terlambat sedikit atau banyak, potongan yang didapat oleh karyawan tetap sama yaitu uang service perhari, masih terdapat banyaknya karyawan yang terlambat menunjukkan bahwa komitmen kerja karyawan Cyclo Coffee \& Apparel Jakarta Selatan masih rendah.Berdasarkan hasil observasi dan pengamatan penulis, motivasi kerja pada Cyclo Coffee \& Apparel Jakarta Selatan belum optimal dikarenakan ada beberapa hak karyawan yang belum diberikan seperti asuransi kesehatan, tidak adanya jenjang karir. Kinerja adalah hasil kerja secara kualitas dan kuantitas yang dicapai seorang pegawai atau karyawan dalam melaksanakan tugasnya sesuai dengan tanggung jawab yang diberikan kepadanya. Oleh karna itu, kinerja akan berjalan dengan efektif apabila didukung 
dengan lingkungan kerja dan motivasi yang optimal.

Lingkungan kerja memiliki arti yaitu keseluruhan alat perkakas dan bahan yang dihadapi, lingkungan sekitarnya dimana seorang bekerja, metode kerjanya, serta pengaturan kerjanya baik sebagai perseorangan maupun sebagai kelompok. Selanjutnya dikatakan Sedarmayanti bahwa suatu kondisi lingkungan dikatakan baik atau sesuai apabila manusia dapat melaksanakan kegiatannya secara optimal, sehat, aman dan nyaman. Keadaan lingkungan yang kurang baik dapat menuntut tenaga dan waktu yang lebih banyak dan tidak mendukung diperolehnya rancangan sistem kerja yang efisien. Dalam hal ini lingkungan kerja berhubungan fisik di mana setiap karyawan dapat memanfaatkan setiap sarana yang ada secara optimal. Lingkungan kerja yang kondusif memberikan rasa aman dan memungkinkan para pegawai untuk dapat bekerja optimal. Lingkungan kerja dapat mempengaruhi emosional karyawan.

Berdasarkan latar belakang tersebut peneliti tertarik untuk menganalisa permasalahan dengan mengambil judul penelitian tentang "Pengaruh Lingkungan Kerja dan Motivasi terhadap kinerja karyawan padaCyclo Coffee \& ApparelJakarta Selatan".

\section{TINJAUAN PUSTAKA}

1. Lingkungan Kerja

Lingkungan kerja adalah kehidupan sosial, politik, dan fisik yang mempunyai pengaruh kepada pekerjaan dan dalam melaksanakan tugasnya. Kehidupan manusia tak lepas dari keadaan lingkungan yang berada di dekatnya, antara manusia dan lingkungan. Beberapa pengertian para ahli tentang lingkungan kerja sebagai berikut:

Sunyoto (2013) mengemukakan dalam jurnal Ummi Kultsum (2017) tentang pengertian lingkungan kerja merupakan segala sesuatu yang ada di sekitar para pekerja dan dapat mempengaruhi dirinya dalam menjalankan tugas-tugas yang dibebankan dan lingkungan kerja fisik mempengaruhi semangat emosi kerja pada karyawan.

Sedarmayanti dalam penelitian yang dilakukan oleh Alif (2015) dalam jurnal Waspodo, dkk (2019) mengemukakan menurutnya bahwa lingkungan kerja adalah keseluruhan alat perkakas dan bahan yang dihadapi, lingkungan sekitarnya dimana seseorang saat bekerja, metode kerjanya, serta pengaturan kerjanya baik sebagai perseorangan maupun sebagai kelompok.

2. Motivasi

Pengertian motivasi dari Abraham Sperling (1987) yang dikutip di buku Mangkunegara (2017) mengemukakan pengertian motif, motivasi dan motivasi kerja bahwa "Motive is defined as a tendency to activity, started by drive and ended by adjustment is said to satisfy the motive" artinya bahwa motif didefinisikan sebagai suatu tendensi kecenderungan untuk beraktivitas, yang dimulai dari dorongan dalam diri (drive) dan diakhiri dengan penyesuaian diri. Penyesuaian diri yang dikatakan untuk memuaskan motif.

3. Kinerja

Istilah kinerja berasal dari job performance atau Actual Performance (Prestasi kerja atau prestasi sesungguhnya yang dicapai seseorang). Pengertian kinerja (prestasi kerja) adalah hasil kerja secara kualitas dan kuantitas yang dicapai oleh seorang pegawai dalam melaksanakan tugasnya sesuai dengan tanggung jawab yang diberikan kepadanya. (Dr, A.A. Anwar Prabu Mangkunegara, Drs.,M.Si.,Psi., 2017)

Kinerja adalah hasil dari suatu proses yang mengacu dan diukur selama periode waktu tertentu berdasarkan ketentuan atau kesepakatan yang telah ditetapkan sebelumnya (Edison, 2016:190)

Berdasarkan pendapat para ahli di atas, dapat disimpulkan bahwa kinerja adalah hasil kerja yang dicapai oleh 
seorang individu yang disesuaikan dengan peran atau tugas individu tersebut dalam suatu organisasi yang dihubungkan dengan suatu ukuran nilai atau standar tertentu dari organisasi dimana individu berkerja

\section{METODE}

Jenis penelitian ini adalah Penelitian deskriptif. Menurut Sugiyono (2017) Penelitian deskriptif merupakan penelitian yang bertujuan untuk memberikan gambaran dari variabel penelitian dimana penelitian ini tidak membuat perbandingan variabel itu pada sampel yang lain dan mencari hubungan variabel itu dengan variabel lain. Dapat berupa penelitian yang lebih luas dan lebih terperinci, dapat dikatakan lebih luas karena masalah yang diteliti tidak hanya masalah sendiri, tetapi juga variabel lain yang berhubungan dengan masalah tersebut. Dikatakan lebih terperinci disebabkan karena variabel tersebut diuraikan atas faktor yang ada. Untuk mendapatkan hasil yang lebih baik, penelitian ini dilakukan dengan menarik sampel. Penelitian ini bertujuan untuk menguji hipotesis, apakah lingkungan kerja dan motivasi berpengaruh terhadap kinerja karyawan di Cyclo Coffee \& ApparelJakarta Selatan

Perusahaan yang menjadi objek penelitian ini terletak di Gedung Crumble Crew, jalan Tulodong Bawah No. 1 A, Kebayoran Baru, Jakarta Selatan. Objek penelitian adalah lingkungan kerja dan motivasi terhadap kinerja karyawan.

Penelitian dalam melakukan penelitian ini dilaksanakan selama periode Oktober 2019 sampai dengan Januari 2020

Dari pendapat di atas, populasi yang dijadikan objek penelitian ini adalah semua karyawan yang bekerja di Cyclo Coffee \& ApparelJakarta Selatan dengan jumlah populasi 52 karyawan.

Menurut Sugiyono (2017:85) sampel jenuh adalah teknik penentuan sampel bila semua anggota populasi digunakan sebagai sampel. Prosedur pengambilan sampel dengan cara pengambilan data dilaksanakan menyebar kuisioner sebanyak 10 pertanyaan lingkungan kerja, 7 pertanyaan tentang motivasi dan 6 pertanyaan kinerja kepada 52 orang karyawan yang dijadikan sampel.

\section{HASIL DAN PEMBAHASAN}

1. Uji Regresi Linear Sederhana

Tabel 1. Hasil Uji Regresi Linier Sederhana VariabelLingkungan Kerja (X1) terhadap Kinerja (Y)

Coefficients ${ }^{a}$

\begin{tabular}{l|l} 
Unstandardized Coefficients & Standardized Coefficients
\end{tabular}

\begin{tabular}{|c|c|c|c|c|c|c|}
\hline & del & B & Std. Error & Beta & $t$ & Sig. \\
\hline & (Constant) & 17.967 & 5.375 & & 3.342 & .002 \\
\hline & Lingkungan Kerja & .134 & .130 & .144 & 1.028 & .309 \\
\hline
\end{tabular}

a. Dependent Variable: Kinerja

Tabel 2. Hasil Uji Regresi Linier Sederhana Variabel Motivasi (X2) terhadap Kinerja (Y) Coefficients ${ }^{a}$

Unstandardized Coefficients Standardized Coefficients

\begin{tabular}{|c|c|c|c|c|c|}
\hline Model & B & Std. Error & Beta & $t$ & Sig. \\
\hline 1 (Constant) & 21.678 & 3.629 & & 5.973 & .000 \\
\hline Motivasi & .069 & .138 & .070 & .499 & .620 \\
\hline
\end{tabular}

a. Dependent Variable: Kinerja

Untuk persamaan $Y$ dari penelitian ini dapat dilihat bahwa dari kolom Unstandardized Coefficients B. Hasil pengolahan data menggunakan SPSS 26 menunjukkan bahwa: $Y=21.678+0,069 X 2$
Maka dapat dijelaskan sebagai berikut :

a. Konstanta sebesar 21.678 menyatakan bahwa jika tidak ada nilai trust maka nilai partisipasi sebesar 21.678.

b. Koefisien regresi $X$ sebesar 0,069 menyatakan bahwa setiap 
penambahan 1 nilai trust, maka nilai

partisipasi bertambah sebesar 0,069.

2. Uji Regresi Linear Berganda

Tabel 3. Uji Regresi Linear Berganda

Coefficients ${ }^{a}$

\begin{tabular}{|l|r|r|r|r|r|}
\hline \multirow{2}{*}{ Model } & \multicolumn{2}{|c|}{ Unstandardized Coefficients } & Standardized Coefficients & & \multirow{2}{*}{ Sig. } \\
\cline { 2 - 6 } & \multicolumn{1}{|c|}{$\mathrm{B}$} & Std. Error & Beta & T & Sig. \\
\hline 1 (Constant) & 7.023 & 5.084 & & 1.381 & .171 \\
Lingkungan Kerja & .228 & .084 & .226 & 2.711 & .008 \\
Motivasi & .647 & .093 & .582 & 6.984 & .000 \\
\hline
\end{tabular}

A. Dependent Variable: Kinerja

Dari hasil pengujian melalui analisis regresi berganda, model regresi dari penelitian ini dapat dirumuskan sebagai berikut: $Y=7,023+0,228 \times 1+$ $0,647 \mathrm{X} 2$

Diinterpretasikan atas persamaan regresi tersebut adalah:

a. Nilai konstanta sebesar 7,023, artinya kinerja karyawan walaupun tanpa dipengaruhi oleh Lingkungan Kerja dan Motivasi sudah mempunyai pengaruh sebesarn 7,023.

b. Pengaruh antar variabel :

1) Pengaruh variabel Lingkungan Kerja terhadap Kinerja Karyawan adalah 0,228 (positif).

2) Pengaruh variabel Motivasi terhadap Kinerja Karyawan adalah 0,647 (positif).

3. Uji Korelasi

Tabel 4. Uji Determinasi

Model Summaryb

\begin{tabular}{lc|r|r|r} 
Model & $\mathrm{R}$ & R Square & Adjusted R Square & Std. Error of the Estimate \\
\hline 1 & $.629^{\mathrm{a}}$ & .464 & .382 & 2.922 \\
\hline
\end{tabular}

a. Predictors: (Constant), Motivasi, Lingkungan Kerja

b. Dependent Variable: Kinerja

Berdasarkan tabel di atas, diperoleh nilai R-square (koefisien determinasi) sebesar 0,464 maka dapat disimpulkan bahwa variabel Lingkungan Kerja (X1) dan Motivasi (X2)

berpengaruh terhadap variabel kinerja karyawan (Y) sebesar 46,4\% sedangkan sisanya $53,6 \%$ dipengaruhi oleh faktor lain yang tidak penulis teliti.

4. Hipotesis

Tabel 5. Hasil Uji t Pengaruh Lingkungan Kerja Terhadap Kinerja Karyawan

Coefficients

\begin{tabular}{|c|c|c|c|c|c|}
\hline \multirow[b]{2}{*}{ Model } & \multicolumn{2}{|c|}{ Unstandardized Coefficients } & \multirow{2}{*}{$\frac{\text { Standardized Coefficients }}{\text { Beta }}$} & \multirow[b]{2}{*}{$\mathrm{T}$} & \multirow[b]{2}{*}{ Sig. } \\
\hline & $\mathrm{B}$ & Std. Error & & & \\
\hline 1 snstant) & 7.023 & 5.084 & & 1.381 & .171 \\
\hline LINGKUNGAN KERJA & .228 & .084 & .226 & 2.711 & .008 \\
\hline MOTIVASI & .647 & .093 & .582 & 1.680 & .000 \\
\hline
\end{tabular}

a. Dependent Variable: KINERJA

Tabel 6. Hasil Uji F

ANOVAa

\begin{tabular}{ll|r|r|r|r|r}
\multicolumn{2}{l}{ Model } & Sum of Squares & df & Mean Square & F & Sig. \\
\hline \multirow{2}{*}{1} & Regression & 8,799 & 2 & 114,399 & 14,704 &, $000^{\mathrm{b}}$ \\
\cline { 2 - 7 } & Residual & 306,182 & 49 & 6,249 & & \\
\cline { 2 - 7 } & Total & 314,981 & 51 & & & \\
\hline
\end{tabular}

A. Dependent Variable: Kinerja

B. Predictors: (Constant), Motivasi, Lingkungan Kerja 
Berdasarkan tabel di atas, maka dapat diketahui Fhitung sebesar 14,704dan nilai ftabel statistik (lihat lampiran) pada tingkat signifikansi 0,05 dengan df 1 (jumlah variabel -1 ) $=2$ dan df 2 (n-k-1) atau 52-2-1 = 49 (n jumlah data dan $\mathrm{k}$ jumlah variabel independen), hasil diperoleh ftabel sebesar 3,19.Dapat disimpulkan bahwa fhitung $>$ ftabel $(14,704>3,15)$ dan signifikansi 0,000 $<0,05$. Artinya terdapat pengaruh antara Lingkungan Kerja (X1), Motivasi (X2) secara simultan terhadap variabel Kinerja (Y).

\section{KESIMPULAN}

Lingkungan kerja tidak berpengaruh positif dan signifikan terhadap kinerja karyawan hal ini dapat diihat dari hasil uji thitung $=1.410$ sedangkan ttabel $=1.676$ (thitung $>$ ttabel) dengan taraf signifikansi 0,165 > 0,05, maka H0 dan Ha diterima.

Motivasi berpengaruh positif dan signifikan terhadap kinerja karyawan hal ini dapat dilihat dari hasil uji thitung $=$ 1.140, sedangkan ttabel $=1.676$ (thitung $>$ ttabel) dengan taraf signifikansi 0,341 >0,05, maka H0 dan Ha ditolak.

Secara simultan dengan uji $\mathrm{F}$ tidak terdapat pengaruh yang positif dan signifikansi secara bersama - sama antara variabel lingkungan kerja dan motivasi terhadap kinerja karyawan pada Cyclo Coffee \& ApparelJakarta Selatan dapat dilihat dari nilai yang diperoleh yaitu Fhitung > Ftabel $(1,122>3,19)$. Hal ini juga diperkuat dengan nilai probability.

\section{DAFTAR PUSTAKA}

AM, E. N., Sarwani, S., Akbar, I. R., Mas' adi, M., \& Maddinsyah, A. (2021). Pengaruh Kedisiplinan Dan Pemberian Kesejahteraan Terhadap Kinerja Pegawai Pada Unit Pelaksana Teknis Puskesmas Wilayah Tangerang Selatan. JENIUS (Jurnal Ilmiah Manajemen Sumber Daya Manusia), 4(2), 185-200.

AM, E. N., Sarwani, S., Akbar, I. R., Mas' adi, M., \& Maddinsyah, A. Pengaruh
Kedisiplinan Dan Pemberian

Kesejahteraan Terhadap Kinerja

Pegawai Pada Unit Pelaksana Teknis

Puskesmas Wilayah Tangerang

Selatan. JENIUS (Jurnal Ilmiah Manajemen Sumber Daya Manusia), 4(2), 185-200.

Arikunto, Suharsimi. 2017. Prosedur Penelitian Suatu Pendekatan Praktek Jakarta: Rineka Cipta

Ghozali, Imam. (2018). Aplikasi Analisis Multivariate dengan Program IBM SPSS

25. Semarang : Badan Penerbit Universitas Diponegoro

Kultsum, Ummi. (2017). Pengaruh Lingkungan Kerja dan Budaya Organisasi Terhadap Efektivitas Kerja Melalui Motivasi Kerja Sebagai Variabel

InterveningPadaPT.TrastiGlobalKon verta.JournalofBusinessStudies. 2,(2).

Mangkunegara, Anwar Prabu. (2017). Manajemen Sumber Daya Manusia Perusahaan. Cetakan 14. Bandung: PT. Remaja Rosdakarya.

Robbins, S. 2016. Perilaku Organisasi. Edisi Sepuluh. Yogyakarta: AndyOffset.

Sugiyono. (2017). Metode Penelitian Kuantitatif, Kualitatif, dan RED.Bandung: Alfabeta, CV

Sunarsi, D., Akbar, I. R., Prasada, D., Kristianti, L. S., Muliani, H. S., Anjayani, N. S., \& Hendra, H. (2020). Pengaruh Kompetensi dan Pengembangan Karir terhadap Kinerja Karyawan pada PT. Berkah Cemerlang di Jakarta. Jurnal Ilmu Komputer dan Bisnis, 11(2), 2465-2472.

Supadi dan Listyasari (2018). Hubungan Antara Lingkungan dan Motivasi dengan Organizationnal Citizenship Behavior (OCB) pada SMA Negeri SeJakarta Timur. Jurnal improvement 5 (1), 110 - 118.

Susanto, Agus dan Sugiyono. (2017). Cara Mudah Belajar Spss dan Lisrel.Bandung: CV Alfabeta.

Sutrisno, Edy. (2017). Manajemen Sumber Daya Manusia. Edisi 1, Cetakan 9.Jakarta: Kencana. 